\title{
Understanding the Implications of Research Skills Development Framework for Indonesian Academic Outcomes Improvement
}

\author{
Prasetyono Hendriarto', Agus Mursidi ${ }^{2}$, Nawang Kalbuana ${ }^{3}$,Nurul Aini ${ }^{4}$, Aslan ${ }^{5}$ \\ 1 Universitas Pakuan, Indonesia \\ 2 Universitas PGRI Banyuwangi Indonesia \\ ${ }^{3}$ Politeknik Penerbangan Indonesia Curu, Indonesia \\ 4 STMIK Dipanegara Makassar, Indonesia \\ ${ }^{5}$ Institut Agama Islam Sultan Muhammad Syafiuddin Sambas, Indonesia
}

\begin{tabular}{|c|c|}
\hline \multirow{3}{*}{$\begin{array}{l}\text { ARTICLE INFO } \\
\text { Article history: } \\
\text { Received } \\
\text { February 02, } 2021 \\
\text { Revised } \\
\text { April 20, } 2021 \\
\text { Accepted } \\
\text { July 11, } 2021\end{array}$} & ABSTRACT \\
\hline & $\begin{array}{l}\text { The qualitative study aimed to understand the Research Skills } \\
\text { Development Framework (RSD) implications for Indonesian master } \\
\text { students' academic achievement. Experience proves that success at the } \\
\text { master's level is closely related to mastering academic research } \\
\text { competencies. A typical study at the master's level requires research skills } \\
\text { to complete tasks and jobs that require research application acuity. To } \\
\text { understand this study's problem, study the data we have done, including } \\
\text { reviewing ten academic findings from international publications, } \\
\text { observing and documenting data related to this topic. After the data was } \\
\text { collected, we were then provided with analysis, including text analysis, } \\
\text { description, coding, and immersion results. Every text is in a language, so } \\
\text { we use a translation application to help us understand Indonesian. To } \\
\text { determine whether the data constitutes a valid and reliable study finding, } \\
\text { we review it and make sure we have answered the study questions. So } \\
\text { the results we can report that the RSD framework has become a } \\
\text { conceptual framework for the development of research skills for } \\
\text { academic and educational needs. The reason is that the RSD framework } \\
\text { is beneficial and useful in working on completing tasks that require skill } \\
\text { in examining problems to find answers. Thus, these findings become } \\
\text { meaningful input for the academic community and other professions. }\end{array}$ \\
\hline & $\begin{array}{l}\text { Keywords: Research Skill Development, Academic Outcome Improvement, } \\
\text { Academic Achievement }\end{array}$ \\
\hline ow to cite & $\begin{array}{l}\text { Hendriarto., et.al., (2021). Understanding the Implications of Research Skills } \\
\text { Development Framework for Indonesian Academic Outcomes Improvement. Jurnal } \\
\text { Iqra' : Kajian Ilmu Pendidikan, 6(2). 51-60. https://doi.org/10.25217/ji.v6i2.1405 }\end{array}$ \\
\hline $\begin{array}{l}\text { Journal Homepage } \\
\text { This is an open acce }\end{array}$ & $\begin{array}{l}\text { http://journal.iaimnumetrolampung.ac.id/index.php/ji/ } \\
\text { s article under the CC BY SA license } \\
\text { https:// creativecommons.org/licenses/by-sa/4.0/ }\end{array}$ \\
\hline
\end{tabular}

\section{INTRODUCTION}

What, exactly, is research for in academic work for? Research begins with curiosity and continues to answer questions we find interesting, and it is essential to know the right way to do this. (Koutsouris \& Norwich, 2018; (Kucirkova \& Cremin, 2020). In general, research in the academic field can be interpreted as an investigation carried out carefully using specific scientific methods to improve learning quality. That is why academics research their studies. Students research because they want to get the "right answers" about a particular academic problem they are investigating. Seeking this truth requires a scientific method because one cannot seek this truth solely by 
relying on intuition or previous experience. Therefore, we see the need to understand the real implications of a research framework in the academic world. We call the Research Skills Development Framework and the implications for Indonesian master students on the academic assignments required to use research skills in their academic life.

The importance of postgraduate students in Indonesia needs to be introduced to the RSD Framework with a research framework. It applies in many higher education institutions in Australasia and the Pacific; this is because since it was developed in 2006 by its initiator Willison \& O'Regan, (2007). Mataniari et al., (2020) It is a nonprescriptive research development format or conceptual spelled out in six necessary research skills recognized by many institutions in Australia and New Zealand for development. The randomness of Information Literacy and adhering to the necessary format in 1956 known as the Bloom taxonomy. When viewed from the basis of its development, the RSD Framework is part of understanding the Engagement Learning and Teaching (MELT) Model from one of the leading universities in Adelaide, South Australia. Many teaching experts argue that the method and formal method of RSD is part of academic learning, especially in postgraduate programs where many of the members are experts in research skills. For example, the skills of searching, synthesizing, analyzing, and analyzing data and communicating the results of the analysis with a specific lightweight scientific study writing format-and quickly followed by academics and outside education. Meanwhile, when viewed from the RSD format, this is a specific study format where the RSD can be applied when reviewing and evaluating the information that has been collected during the stages of research work among academic tasks.

Efforts to develop academic skills such as research taking can be made in many ways. One of them is the development of the concept of research skills. The skills referred to in the RSD concept are skills related to finding data, understanding, and understanding, and applying data and information in various opportunities and contexts, such as cultural context, academic scope, and technology-based innovation. Every educational institution can produce graduates with the skills and skills in scientific activities that require research skills. These institutions must produce graduates competent in research abilities to welcome and overcome obstacles and challenges of work in the future. So that is when it is necessary to learn and strengthen research skills with the right concept structure in developing these skills from the school, university-level to postgraduate university, or work world.

Efforts to apply the RSD framework at the university level can be made in each faculty or library section. The appropriate application is usually carried out in university and state library sections by applying the RSD Framework as part of the basic formation of introductory activities. At once-great, the development of skills studies skills in the RSD framework. Any arrangement and development of groups of research skills activists, institutional policies that support postgraduate students in their research development journey must be fully supported. Furthermore, in developing the RSD framework, some aspects or facets are owned in the RSD framework program. Skills or facet divine facets will later provide insight and research conceptual that will help undergraduate students deal with each task and learning.

This RDS program and development concept has opportunities for both students and individuals interested in this research framework. This development is adjusted, or directed in advance, for postgraduate students in the university environment to access competency research development related to aspects through various research 
study solutions and training time arrangements that are most suitable for students. This RSD framework application program also reflects a straightforward and flexible delivery compiled by each university, the center for master students to feel suitable for learning a practical and useful RSD framework.

The RSD framework and development program has grouped a series of experts and online format content that is continually being renovated and designed by university staff in charge of the library section with disciplinary skills and competencies and technical expertise in the RSD framework section. Human resources and material are organized in many studies, such as the database for learning management of RSD research studies and university institutions, which can also be accessed via the library website. Other options and programs, including face-to-face online events, including in conventional classroom learning, micro-group learning, or person-to-person meetings, can also be directed.

One of the examples of benefits we have identified is the RSD framework used at the university of using as an essential media based on internationality recognized best usage standards, such as the conceptual of the RSD Framework, is running an organized, scaffolding, no fixed approach to research abilities across the faculty curriculum. The skill of mapping research capabilities across the institution also supports the approach's accuracy and achievement. As such, the RSD's center-facultyinformed action and collaborative strategy explore the usefulness of systematic assessment achievement, programming from non-degree / double degree students to master program studies already applied at the University of Waikato. Based on usability and working in applying the RSD framework, it is this that has moved us research researchers in academic programs. Each model framework (research development that can help transfer these skills to Indonesian academics to be involved in studies and use each study's results to develop research skills in academic and other non-academic ways.

Observing the state of active competition and the reputation of Indonesian researchers who are still in a low position compared to the reputation of researchers outside the country, let us say that the country of origin of this RSD framework was initiated, here we can understand that Indonesian researchers need alternative solutions with potential research models and frameworks. For example, the RSD framework model initiated by John Willison and Kerry O'Regan (Adelaide, AU) has been tested to be one of the models applied in many research contexts outside countries such as Europe, America, and other Asia. Using analyzing and innovating the curriculum to manage research skills, both students and researchers outside academics. This model is indeed easy to apply in a descriptive, scalable, and useful way for completing assignments, academic courses, or other non-academic learning program planning purposes Hutagaluh et al., (2020). They said that the RSD framework is suitable for use in the Indonesian context, especially in higher practical education, which involves intensive research activities.

\section{METHOD}

Efforts to understand the implications of the framework for developing research skills to improve Indonesian academics' intellectual work is the main objective of this study. The steps we have taken are collecting the RSD framework literature and visiting ten international journal publications that have discussed the benefits and advantages of this research framework initiated by this Australian researcher. After the data is collected, we then analyze it by involving system coding, evaluating the 
resulting results and guidelines on study problems. We believe that these findings are valid and reliable data based on the clear transparent findings that are very suitable in answering this model research question. Because this is current data, we do all processes by utilizing online data assisted by Google searching and editing applications to report research results. Likewise, we also follow this draft research by the experts' guidelines (Ridder, 2014; Engle, 2015; Sgier, 2012) in their working paper, qualitative data analysis, and review.

\section{RESULT AND DISCUSSION}

Venning with Venning \& Buisman-Pijlman, (2013) has succeeded in integrating an evaluation matrix on feedback when encouraging efforts to improve skills and expertise in research activities on research projects in postgraduate programs in Australian universities. Their studies were successful in their assignment efforts with the RSD framework's help with students focusing on the study department. In their study, the postgraduate students succeeded in applying the matrix to support students studying postgraduate projects, especially Adelaide University. All parties involved in this study all come from different majors, but they have benefited from this RSD framework with standard support from the RSD framework. Another benefit of their study is that through a matrix study, they can improve the alignment of work and academic assignments starting from the initial process entering the review stage, searching for data, analyzing to reporting the results of their study complete with feedback from seniors and RSD experts, an integral part of taking advantage of research skills.

Willison \& Buisman-Pijlman, (2016) has successfully resulted in a program to increase research expertise for Ph.D. candidates while they are students. With the study's primary aim, they wanted to examine the impact of developing the RSD framework on various majors in the several semesters before students achieve their Doctor degree. Through interviews with nine teachers and researchers and 14 Doctoral students. At the final stage, the authors have heard about the RSD framework's benefits during their time as doctor candidates. As for the skills that the researchers managed to get, for example, metacognition skills in research. These skills are beneficial for students, work, and think like senior researchers. Other expertise is, for example, the development of feasibility of researching the education section.

At the end of their report, they succeeded in hearing the recognition of this Doctorate candidate so that the RSD framework was taught at the early expose so that candidates get the perfect development of this academic research so that their college career journey is smooth and satisfying results. In practical terms, this finding implies the suitability between the college majors and the research development framework so that all students can bring these skills to their home country so that more researchers are interested in the format and concept of developing research under the auspices of the Australian government for the benefits and ease of application because of its value and practicality. Results in research development explicitly across all Ph.D. programs, or avail of a candidate preparation concept.

Meanwhile, Bandaranaike, (2018) findings reveal that it is necessary to develop skills in the world of work later by developing study expertise. He proved that starting with students' thinking and collaboration at the university in research activities can positively impact work skills when students return to work. In other words, he wanted to say that the excellence of this RSD was able to provide a different color in a work career if, since graduation, students were involved in research activities. When the 
study was carried out, they were still in a transitional period, so the most appropriate time was to facilitate RSD and working integrated learning or WIL.

According to Bandaranaike, (2018) efforts to overcome challenges when the world of work enables students to connect virtually with the industry's desires in the future. With the hope that this work is to support work on applying a validated framework, a framework for improving work skills, and supporting students with evidence of this framework's effectiveness in the world of work full of work skills and full autonomy. In the end, he said that the development of work skills could contribute to pedagogy and has a direct application to the contribution of tertiary education to improving future work mindsets, bridging successes between studies and entering the industrial world of the advanced era.

The next finding came from the framework of the RSD initiator, Willison, (2012) which proves that when university staff, especially lecturers and researchers, integrate this RSD framework into the college curriculum content, he can prove that students can hone a lot of research academic skills and expertise for applied disciplines each. Willison has also helped further, especially for future work involving research activities in all professional worlds. Overall, he revealed that academics' research activities show that a period of skills training that examines students leads to effective management, supports academics to reveal the study's main objectives, and helps them identify in-depth feedback to students that format and conceptualize their past. They also explained that academics who explained this educational process distinguished students' perceptions of studying activities in various departments and even stated the direction of student study activities.

Further findings from Mataniari et al., (2020) have successfully illustrated the ability to think sharply of students with the help of the research Framework in the Biology program department at a university in Indonesia. These findings support the initiator of the conceptual framework by its initiator, Willison, in 2012. Both findings have proven that the teaching staff and researchers have incorporated the university curriculum's RSD framework. Besides, as the originator of the RSD idea, Willison has also supported researchers' work in the future by involving high study activities in many professionals. Finally, they concluded that the university study program is beneficial for academics through research training that supports students in managing and supporting academics to achieve the ends of each study and help researchers express appropriate feedback to academics with conceptual research. Furthermore, academics also explained that they were able to go through the challenging process of academic assignments. This work has explained different perceptions of skills research between students and lecturers in the Department of Biology with research activities, even explaining the purpose of student academic activities in the Biology program.

Willison \& O'Regan, (2007) have successfully written their findings on the topic of study. Some are commonly known, some are generally not understood, some are entirely unknown and understood: Their study wants to say that with a research framework and skills right, it is easier for students or researchers to work as professional researchers. This study has contributed to studying topics that are very difficult for undergraduate students with research concepts emphasized by re-proofing the format of teaching in universities. Even though their study seems unclear, it has concrete empirical facts complete with very connected theories. Through this study, the authors also suggest that theoretical studies are related to undergraduate studies and present an RSD framework, which is easy to apply when mapping and honing students' academic research skills. The final section provides a presented example of 
this research concept's practical application, with previous studies' findings. After initiating the second RSD framework, this first research also quoted the legendary scientist's quote, "I am not very smart and not very loving." "I am just very, very curious."

The findings of Willison Dr, (2018) have successfully articulated the task of activities that educators often do when academics facilitate students' research activities with in-depth exploration by sharpening their developing skills in thoroughness and seriousness. This special issue contains eight topics that discuss criticism of the RSD framework, analysis, and RSD application. (Goldstein, 2020; Putra et al., 2020; Ain et al., 2019; Smith, 2010). The study also brings a new edition with the latest version of the RSD presentation in 2018, in response to the 12 years of developing the RSD framework. The addition and development of RSD are also improvements in matriculation and other aspects of skills, expansion of more measured autonomy, and development of functional domains and grouping problems. The other seven publications, five of which were written in the undergraduate years and two topics by student masters, were in biology, education and teaching, engineering and engineering, humanities, and other multidisciplinary studies. This study also started on many changes, including studies in the laboratory, the application of online databased studies, literature learning, and the world of vacations. Of these seven, one sharply discusses the development framework of RSD, three focuses on the innovation curriculum, and three of them connect the RSD framework to old issues that are currently trading topics by adapting the framework for accelerating academic literacy skills problem solutions. These three combinations serve as examples of future models that update the terminology and format of the RSD framework in its broadest sense and deepen subsequent editions as new models of engaged learning and teaching.

Wilmore \& Willison, (2016) discusses the behavior of graduates who are careered in various industries to develop study competencies during the study program. Through interviews with ten graduates who have different assignments, then about one year after graduating, they understand how they can apply their media studies skills as themselves. This study was carried out as part of a more tasked project by evaluating the framework's application by systematically increasing study skills. The interviews' results revealed a broad understanding of the value of research proficiency for media project work. However, there are conflicting opinions about the importance of clearly sharpening research skills and the value of the media section's unique abilities in the current task situation.

The data sources also show varying degrees of understanding of the suitability of research skills across different job conditions. Therefore, media lecturers must understand how to get different student media sections' unique abilities in the world of formal and informal work towards the quality of their majors. The second researcher concluded that this educational problem was at least handled by applying the right work format for studies in the field of education so that it could increase students' metacognitive awareness after the transfer of these graduate skills in various industries and future job goals.

We are referring to the ten international publications that we studied with the primary objective of discussing the implications of a Research Skills Development Framework for Indonesian Academic outcomes improvement. Discussion of the findings, we would like to answer whether the results of our study match the expectations of the topic of this paper, in other words, whether our findings support our presumption or not. Here we want to contextualize the findings of this RSD 
framework study about existing theories and previous studies. So for that, we can explain that the ten publications of our review have become material for evaluating the academic research development framework with a very significant significance. We consider every input with possible explanations and alternatives present in this section of the discussion do not make our findings stand out. So let us start with the first findings of the initiator of the RSD framework.

The findings of John Willison, who say the importance of the RSD framework, are very much in line with our findings. He mentioned that the usefulness and ease of applying this research framework are empowering research skills during his academic years or after graduating from college. The ten papers studied firmly proved that the RSD framework application is very suitable in the college-level curriculum. Where typical academic assignments at the university level at postgraduate level require research skills and reporting skills can raise new findings to contribute to the world of new knowledge so that it is increasing is easy for students to work during their studies and the workforce.

When viewed from the development of the ability to research Indonesian students and academics, it may still be said that something is challenging and even tricky. Maybe the problem of research skills is still a select item for some academics. Nevertheless, this RSD framework is a research framework that is easy to apply, and this is very important for both students and postgraduate students themselves. Unlike the ten topics we studied, they face many problems where they have made the RSD framework a study format and concept, which is very interesting and transparent in its application. This is following Sekaran \& Bougie, (2016) recognition, which states that research application and methods for business and education in academics are so interesting. So in scientific development through research such as the RSD framework, the benefits for academics are apparent and straightforward. This is one of the features of this research framework to improve student research quality at universities. Students and the Indonesian scientific community's lack of publications have made some Indonesian academics and scientists not fulfilled in the scientific world and other roles. Adnan, (2009) stated that some problems for publication research articles written by academics submitted to international English language journals are more rejected as they are not correctly written with a lack of many issues.

Based on its development, this RSD framework was developed to help students at the postgraduate level from the initiator's experience that many students have difficulty adjusting to the typical assignments in a university environment that prioritize research and writing skills. This research framework develops because of its very high utility and absorption capacity for academic scientists both in Australia and abroad. This has been a very successful study and development with the release of its international publication. However, the initiators still wanted to develop the RSD framework to be an asset that many academics can apply at western and non-eater universities, such as the context of academics in Indonesia, which is still challenging to apply to concepts developed in the new world with a critical and in-depth study and framework such as the RSD study. Perhaps academics in Indonesia can observe the development of international publications from Indonesian national writers, which are still very low compared to foreign publications relatively high and in journals with a very high impact. (Azizah \& Budiman, 2018).

Adnan, (2014) also added that with the few international studies findings from Indonesian authors, Indonesian researchers' proficiency and participation are still low; we continue to seek a kind of RSD framework. More and more Indonesian academics 
are motivated by the findings of the application of this RSD framework. Indeed, not many Indonesian academics publish research in international journals. It could be due to a lack of information or even a lack of encouragement in the format and concept of a research framework that is suitable and easy for Indonesian researchers to follow. Alternatively, Hill \& Wie, (2012) added that maybe the awareness of Indonesian academics has not increased like other international researchers even though the Directorate of Higher Education, which was previously under the Ministry of Education and Culture, had quite a lot of attention disbursement. However, it turns out that now under the Ministry of Research, Technology, and Higher Education, it has provided media in the form of the Student Creativity Program, which is held not to worry anymore about funds. However, participation is still minimal compared to the number of UPI students who should contribute more than 1000 proposals. So with the encouragement and initiation of various scholarship frameworks, Indonesian students and researchers can be more advanced and innovative. Finally, with the emergence of various publications that accentuate various kinds of research frameworks and concepts for the development of writing and research skills, it is hoped that many researchers will be able to become competent and interested in the RSD framework, which is increasingly appearing in international journals.

\section{CONCLUSION}

As stated earlier, this study aims to understand the implications of the Research Skills Development (RSD) framework on Indonesian master students' academic achievement. Of the ten topics of international publication that we have reviewed, it has produced results following our assumption that the success of postgraduate students in their study assignments will be satisfied if they are supported by the skills and skills to do adequate studies during their time as students when they return to the industrial career community. From the results of our study and the available data, we can consider that this study's results prove that the research framework's skills much help study at the postgraduate level. Likewise, when viewed from the specific aspects of lectures at the master's level, it requires assistance and encouragement so that students can carry out research to complete assignments and jobs that require research application acuity. Hence, the result we can report that the RSD framework has become a conceptual framework for developing research skills for academic and educational needs. The reason is that the RSD framework is useful and useful in doing tasks that require skills in researching problems to find answers. Thus, these findings become meaningful input for academics and other professions.

\section{ACKNOWLEDGEMENT}

We authors are to express our gratitude to all support given during the writing process of this paper especially my department supervisors who were dedicatedly providing feedback and support to our project entitle " Understanding the Implications of a Research Skills Development Framework for Indonesian Academic Outcomes Improvement".

\section{AUTHOR CONTRIBUTION STATEMENT}

The advantages possessed by most research development concepts include the ability of researchers or students to think critically in completing scientific learning assignments and job assignments in outside academic careers. With the potential for RSD integrity, the critical potential remains prime. For example, a recent study by 
Mataniari et al., (2020) examined the potential for critical thinking skills through the RSD Framework among Biology students at Indonesian University. In particular, this research is very contributive because it is very beneficial for students to use the RSD framework in compiling their lab reports. Likewise, other findings even though this research concept is only 12 years of development. The results show the many benefits of critical thinking self-contribution and student autonomy in working in tasks that require practical research concepts such as the RSD framework.

\section{REFERENCES}

Adnan, Z. (2009). Some potential problems for research articles written by Indonesian academics when submitted to international English language journals. The Asian EFL Journal Quarterly March 2009 Volume 11, Issue, 107. Google Scholar

Adnan, Z. (2014). Prospects of Indonesian research articles (RAs) being considered for publication in 'center'journals: A comparative study of rhetorical patterns of RAs in selected humanities and hard science disciplines. Dalam Occupying niches: Interculturality, cross-culturality and aculturality in academic research (hlm. 79-99). Springer, Cham. Google Scholar

Ain, C. T., Sabir, F., \& Willison, J. (2019). Research skills that men and women developed at university and then used in workplaces. Studies in Higher Education, 44(12), 2346-2358. https://doi.org/10.1080/03075079.2018.1496412

Azizah, U. A., \& Budiman, A. (2018). Challenges in writing academic papers for international publication among Indonesian graduates students. JEELS (Journal of English Education and Linguistics Studies), 4(2), 175198.https://doi.org/10.30762/jeels.v4i2.405

Bandaranaike, S. (2018). From research skill development to work skill development. Journal of University Teaching \& Learning Practice, 15(4), 7. Google Scholar

Engle, M. (2015). Book Review: Qualitative Data Analysis: A Methods Sourcebook: The Coding Manual for Qualitative Researchers. https://doi.org/10.1177\%2F1098214014556146

Goldstein, D. (2020, Juni 5). Research Shows Students Falling Months Behind During Virus Disruptions. The New York Times. https://www.nytimes.com/2020/06/05/us/coronavirus-education-lostlearning.html. Google Scholar

Hill, H., \& Wie, T. K. (2012). Indonesian universities in transition: Catching up and opening up. Bulletin of Indonesian Economic Studies, 48(2), 229251.https://doi.org/10.1080/00074918.2012.694156

Hutagaluh, O., Manullang, S. O., Hamid, M., Arief, A. S., \& Abdurrahman, D. (2020). How the research skills development framework may be useful for indonesian higher education learning practice. Nidhomul Haq: Jurnal Manajemen Pendidikan Islam, 5(3), 347-359.https://doi.org/10.31538/ndh.v5i3.967

Koutsouris, G., \& Norwich, B. (2018). What exactly do RCT findings tell us in education research? British Educational Research Journal, 44(6), 939959.https://doi.org/10.1002/berj.3464

Kucirkova, N., \& Cremin, T. (2020). Children Reading for Pleasure in the Digital Age: Mapping Reader Engagement. Sage. Google Scholar

Mataniari, R., Willison, J., Hasibun, M. E., Sulistiyo, U., \& Fatria, D. (2020). Portraying Students' Critical Thinking Skills through Research Skill Development (RSD) Framework: A Case of a Biology Course in an Indonesian University. Journal of Turkish Science Education, 17(2), 302-314. Google Scholar 
Putra, P., Mizani, H., Basir, A., Muflihin, A., \& Aslan, A. (2020). The Relevancy on Education Release Revolution 4.0 in Islamic Basic Education Perspective in Indonesia (An Analysis Study of Paulo Freire's Thought). Test Engineering $\mathcal{E}$ Management, 83, 10256-10263. Google Scholar

Ridder, H.-G. (2014). Book review: Qualitative data analysis. A methods sourcebook (Vol. 28). Sage publications Sage UK: London, https://doi.org/10.1177\%2F239700221402800402

Sekaran, U., \& Bougie, R. (2016). Research methods for business: A skill building approach. John Wiley \& Sons. Google Scholar

Sgier, L. (2012). Qualitative data analysis. An Initiat. Gebert Ruf Stift, 19, 19-21 Google Scholar.

Smith, K. (2010). Research, policy and funding-academic treadmills and the squeeze on intellectual spaces 1. The British Journal of Sociology, 61(1), 176195.https://doi.org/10.1111/j.1468-4446.2009.01307.x

Venning, J., \& Buisman-Pijlman, F. (2013). Integrating assessment matrices in feedback loops to promote research skill development in postgraduate research projects. Assessment \& Evaluation in Higher Education, 38(5), 567579.https://doi.org/10.1080/02602938.2012.661842

Willison Dr, J. W. (2018). Research skill development spanning higher education: Critiques, curricula and connections. Journal of University Teaching $\mathcal{E}$ Learning Practice, 15(4), 1.Google Scholar

Willison, J., \& Buisman-Pijlman, F. (2016). PhD prepared: Research skill development across the undergraduate years. International Journal for Researcher Development. http://dx.doi.org/10.1108/ijrd-07-2015-0018

Willison, J., \& O'Regan, K. (2007). Commonly known, commonly not known, totally unknown: A framework for students becoming researchers. Higher Education $\begin{array}{llll}\text { Research } & \mathcal{E} & \text { Development, 393-409. }\end{array}$ https://doi.org/10.1080/07294360701658609

Willison, J. W. (2012). When academics integrate research skill development in the curriculum. Higher Education Research \& Development, 31(6), 905919.https://doi.org/10.1080/07294360.2012.658760

Wilmore, M., \& Willison, J. (2016). Graduates' attitudes to research skill development in undergraduate media education. Asia Pacific Media Educator, 26(1), 113128.https://doi.org/10.1177\%2F1326365X16640348

Copyright Holder :

(c) Hendriarto., et.al., (2021).

First Publication Right :

(c) Jurnal Iqra' : Kajian Ilmu Pendidikan

This article is under:

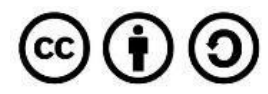

